\title{
Effect of LES on Recovery Capability of DNCB-Induced Allergic Contact Dermatitis in Rat
}

Jeong Sook Kim', Young Mi Park', Jin Boo Jeong², Jae Hwan Lim', Hyung Jin Jeong² and Eul Won Seo'*

\author{
${ }^{1}$ Department of Biological Science, Andong National University, Andong 760-749, Korea \\ ${ }^{2}$ Department of Medicinal Plant Resource, Andong National University, Andong 760-749, Korea
}

Received February 7, 2011 /Accepted April 8, 2011

\begin{abstract}
In this study, we evaluated whether Lunasin Enriched Soybean (LES) suppressed 1-chloro-2,4-dinitrochlorobenzene (DNCB) induced allergic contact dermatitis in vivo. In the group treated with DNCB alone, erythema and hemorrhage in the skin were observed, while the application of LES after DNCB treatment modulated erythema and hemorrhage similar to the untreated group. In histopathological analysis of the skin, DNCB-treated groups showed increased skin thickness compared to the untreated groups, while the treatment of LES dose-dependently modulated skin thickness. Also, hypertrophy and hyperkeratosis of the epidermis, intracellular edema and infiltration of inflammatory cells were observed in the group treated with DNCB alone, while treatment of LES inhibited these inflammatory changes. DNCB also induced a significant up-regulation of iNOS and COX-2 expression, as compared to the untreated groups. However, the treatment of LES significantly decreased the down-regulation of iNOS and COX-2 expression, as compared to DNCB-treated groups. Also, LES reduced the IgE level in DNCB-stimulated groups. And lunasin from LES translocated the nucleus of the cells in the skin of Sprague-Dawley rats. Taken together, it is thought that LES has the potential to be used as an alternative treatment for allergic contact dermatitis.
\end{abstract}

Key words : Lunasin Enriched Soybean (LES), lunasin, allergic contact dermatitis, iNOS, COX-2, allergen

\section{서 론}

산업 발달에 따른 환경오염이 가속화되면서 각종 면역과민 성 질환을 유발하는 알레르겐이 급증하고 있어 현대인은 알레 르기성 질환인 기관지 천식, 비염, 알레르기성 결막염 및 아토 피성 피부염 등에 노출되어 있다[10]. 알레르기 유발물질은 주 로 소화기, 중추신경계 및 피부에서 나타나며, 특히 피부 질환 중에서 접촉성 피부염은 화학물질, 약물 및 기타 자극물질에 의해 유발된다[3].

알레르기성 접촉피부염은 $\mathrm{T}$ 림프구와 대식세포 등에 의해 서 발생되는 세포성 면역과민반응으로 $\mathrm{T}$ 세포의 활성, 증식에 의해 항원 특이적 세포 독성 $\mathrm{T}$ 림프구의 활성 등 다양한 항원 특이적 반응이 일어난다. 이러한 반응에 관여하는 사이토카인 은 IL-1, IL-2, IL-3, IFN- $\gamma$ 등으로 각질형성세포의 성장을 자 극하여 상피 과형성과 과립성 대식세포의 자극 물질의 분비 촉진, 랑게르한스 세포수의 증가, 각질형성세포의 증식 등이 촉진된다. 또한 우리 주변의 환경오염과 공해로 인해 우리 몸 에서는 과량의 활성산소가 생성되며, 이것은 불포화지방산과 결합하여 지질과산화를 유발하게 되며 피부의 최상층인 각질

*Corresponding author Tel : +82-54-820-5462, Fax : +82-54-820-7705

E-mail : ewseo@andong.ac.kr
층에 부착되어 피부의 보습력을 약화시켜 염증을 악화시키게 된다 $[9,13,20]$.

알레르기성 접촉피부염을 치료하기 위해 부신피질 호르몬 제 및 항히스타민제가 사용되고 있으나 장기간 투여할 경우 여러 가지 부작용이 보고되고 있어 이에 대한 새로운 치료제 의 개발이 필요한 실정이며, 특히 항 알레르기제의 개발과 관 련되어 천연재료인 약용식물이 우선적으로 선택되고 있다 [24]. 대두로부터 확인된 lunasin은 43개의 아미노산으로 이루 어진 대두 펩타이드로서 대두 단백질 1 그램당 약 5.48-16.52 $\mathrm{mg}$ 이 들어 있으며, 열에 매우 안정한 특성을 갖고 있다. 이러 한 lunasin은 세포의 신호전달에 필수적인 막 integrin과도 경 쟁적으로 결합하는 특성을 갖고 있어 피부 종양에 도포하는 경우 종양의 $70 \%$ 를 경감시키며 종양의 출현도 지연시키는 효 과를 나타낸다고 한 바 있으며[7], 암세포에 주입하면 세포분 열을 정지시켜 사멸에 이르게 한다고 보고한 바 있다[6]. 그러 나 이러한 lunasin은 순수정제가 어렵고, 부대 비용이 많이 들기 때문에 실질적인 실용화에 어려움이 있는 실정이다. 그 러나 대두 추출물인 LES (Lunasin Enriched Soybean)는 luna$\sin$ 이 함유된 부분 정제된 조추출물로서 최소비용으로 대량 추출할 수 있기 때문에 기능성 소재로서의 활용가치가 매우 높은 편이다[21]. 따라서 최근 현대인에게 매우 빈번하게 발생 하는 알레르기성 접촉피부염에 lunasin 함유 대두 추출물인 
LES가 알레르기성 접촉피부염에 미치는 효과를 살펴보는 것 은 대두의 또 다른 생물학적 기능을 밝히는 연구가 될 것이다.

따라서 본 연구에서는 DNCB에 의해 인위적으로 알레르기 성 접촉피부염을 유발시킨 랫드에 LES를 처리하여 피부 회복 능에 미치는 영향을 조사함으로서 LES가 알레르기성 반응의 억제 및 피부 회복에 미치는 영향을 살펴보고자 하였다.

\section{재료 및 방법}

\section{실험동물 및 시약}

생후 4주령 Sprague-Dawley 수컷 랫드를 샘타코(주)에서 구입하여 고형사료와 탈이온수를 자유롭게 섭취시키면서 사 육실 환경에 1주일간 적응시킨 뒤 체중 $150 \pm 10 \mathrm{~g}$ 랫드를 선별 하여 실험에 사용하였다. 사육실의 온도는 $21.4 \pm 0.05^{\circ} \mathrm{C}$, 습도 $61 \pm 1 \%, 12$ 시간 명암주기하에서 사육하였다. 모든 동물실험 과 정은 $\mathrm{NIH}$ 의 실험동물관리 규정과 안동대학교의 실험동물 관 리와 사용 지침의 규정에 따라 수행하였다. 본 연구에 사용된 시약은 Sigma (St. Louis, USA)로부터 구입하였으며, 기타의 시약은 별도로 표기하였다.

\section{LES의 추출}

LES는 Park 등[21]의 방법을 이용하여 추출하였다. 본 실험 에 사용한 대두(Glycine max)는 황금콩으로서 대두분말에 protease inhibitor가 포함된 phosphate buffered saline (PBS, pH 7.4)를 혼합하여 $4^{\circ} \mathrm{C}$ 에서 48 시간 진탕하였다. 추출액은 투석을 실시한 후, 원심분리를 하여 조추출물을 얻었으며, 단백질 농 도는 Bio-Rad Labs (Hercules, CA)의 protein assay kit를 사용 하여 측정하였다. 이러한 조추출물로부터 부분 정제된 lunasin 즉 LES를 얻기 위하여 Biogel resin AG 1-X4 (mesh size, 100-200)을 사용한 ion exchange column chromatogrphy를 실 시하였다. 사용한 column의 크기는 $5 \mathrm{~cm} \mathrm{x} 50 \mathrm{~cm}$ 로 $0.1 \mathrm{M}$ $\mathrm{PBS}$ (pH 7.0)로 평형화 시킨 후 조추출 단백질을 주입하였으 며 $4^{\circ} \mathrm{C}$ 에서 $0.7 \mathrm{M} \mathrm{NaCl}$ 으로 용출하였고 수집된 분획으로부 터 lunasin을 확인한 후 동결 건조하여 본 연구의 시료로 사용 하였다(data not shown).

\section{$\mathrm{DNCB}$ 제조와 도포에 의한 알레르기성 접촉피부염 유발}

랫드로부터 인위적인 알레르기성 접촉피부염을 유발시키 기 위하여 DNCB (1-chloro-2,4-dinitrochlorobenzene, SigmaAldrich, USA)를 acetone과 olive oil이 3:1로 혼합된 용액에 $2.5 \%$ 와 $1.0 \%$ 로 희석하여 사용하였다. 1 주일간 사육환경에 적 응시킨 랫드의 등 부위를 제모하고 피부의 미세 상처가 치유 되도록 24시간 방치하였다. 1 차로 $2.5 \% \mathrm{DNCB}$ 용액 $1 \mathrm{ml}$ 로 등 부위에 도포하여 면역반응을 유발하였고 이 후 4 일이 경과 한 후 1 주일에 3회씩 2주 동안 $1 \% \mathrm{DNCB}$ 용액 $1 \mathrm{ml}$ 를 등에 도포하였다. 실험군은 정상군(Normal Group), 대조군(Control
Group, DNCB에 의해 알레르기성 접촉피부염이 유발된 실험 군) 및 대조군에 LES $17.6 \mathrm{mg} / \mathrm{ml}$ 을 3회 도포한 LES-3군과 5 회 도포한 LES-5군으로 나누어 각 실험군 당 6 마리씩 실험에 사용하였다. 실험 목적에 따라 랫드를 희생하여 혈액, 피부 및 간을 적출하였다.

\section{조직학적 관찰 및 immunostaining}

피부의 조직학적 구조는 일반적인 조직 제작 방법에 따라 파라핀 포매 하였으며 헤모톡실린과 에오신에 이중염색한 후, 광학현미경(Olympus BX50, Japan) 하에서 관찰하였고 Olympus DP-71를 사용하여 사진 촬영을 하였다. 피부표면의 초미세 구조는 조직을 glutaraldehyde (Ted Pella Inc., Redding, $\mathrm{CA}$ )에서 2시간 전고정 하였고, $0.1 \mathrm{M}$ phosphate buffer ( $\mathrm{pH}$ 7.0)로 수세하였다. 후고정은 1\% osmium tetraoxide (Ted Pella Inc., Redding, CA)에 고정시켰으며 완전히 건조시킨 후 금코팅을 하였다. 관찰은 주사전자현미경 (Hitachi S-2500C, Japan) 하에서 수행하였다.

LES에 포함된 lunasin의 세포 내 전달 기작은 anti-lunasin polyclonal antibody를 사용하여 immunostaining을 실시하여 확인하였다. 접촉피부염이 유발된 조직에 1 차로 $0.1 \%$ saponin/PBS/FBS에 anti-lunasin polyclonal antibody (Zymed Laboratories, San Francisco, CA)를 처리하였고, 2차로 goat anti-rabbit fluorescent isothiocyanate (FITC)-conjugated secondary antibody (Santa Cruz Biotechnology, Santa Cruz, $\mathrm{CA}$ )를 암소에서 처리하였다. 조직의 관찰은 형광현미경 (Olympus BH-2, Japan)을 이용하여 DAPI는 $359 \mathrm{~nm}$, lunasin 은 $461 \mathrm{~nm}$ 에서 관찰하였다.

\section{혈장분석}

혈장내의 아미노산 전이효소(AST, ALT), 총콜레스테롤 (T-Chol) 및 중성지방(TG) 은 혈액분석기(Hitachi 7600)에서 분석하였다.

\section{혈장 내 $\operatorname{lgE}$ 수준의 측정}

혈장 내 IgE의 수준은 Rat IgE ELISA kit (Uscn Life Science Inc., China)를 사용하여 protocol에 따라 $450 \mathrm{~nm}$ 에서 측정하 였다.

\section{iNOS와 COX-2의 활성}

$\mathrm{iNOS}$ 와 COX-2의 활성은 랫드의 피부조직으로부터 lysis buffer ( $50 \mathrm{mM}$ Tris - $\mathrm{HCl}, \mathrm{pH}$ 7.4, $150 \mathrm{mM} \mathrm{NaCl}, 1 \mathrm{mM}$ EDTA, $1 \mathrm{mM}$ EGTA, $10 \mathrm{mg} / \mathrm{ml}$ aprotinin, $10 \mathrm{mg} / \mathrm{ml}$ leupeptin, $5 \mathrm{mM}$ phenylmethylsulfonyl fluoride 및 $1 \mathrm{mM}$ DTT) 를 이용하여 단백질을 추출한 후 western blot을 통해 확인하 였다. 


\section{통계처리}

모든 실험은 독립적으로 3 회 이상 반복으로 이루어졌으며 각 실험에서 얻어진 결과는 평균 \pm 표준편차로 나타내었다. 통 계처리는 SPSS 12로 분석한 후 t-검정을 실시하여 분산과 평균 의 동일성 여부를 검정하였으며, 분석결과는 일원분산분석 (one way ANOVA)에 의한 Duncan 검정을 실시하였으며, $p$ 값이 0.05 미만일 때 유의한 것으로 간주하였다.

\section{결과 및 고찰}

LES가 DNCB에 의해 유도된 접촉피부염에 미치는 조직학 적 영향

본 연구에서는 LES의 알레르기 접촉피부염에 대한 회복능 을 조사하기 위하여 정상군과 $\mathrm{DNCB}$ 로 알레르기 접촉피부염 을 유발시킨 대조군 및 대조군에 LES를 도포한 실험군으로 나누어 실험을 실시하였다. 육안적 관찰에서 대조군은 등 부 위에 피부 반점, 홍반, 피부 건조, 부종 및 출혈 등이 심각하게 나타났다(Fig. 1B). 이러한 상태의 랫드에 LES를 3회 도포하면 환부의 피부염은 급격히 호전되고 있으며(Fig. 1C), 5 회 도포 시에는 거의 정상 피부 상태로 회복되었다(Fig. 1D). 주사전자 현미경적으로 피부 표면을 관찰해 보면 정상군에서는 피부 표면이 깨끗하고 매끄러운 형태로 나타났으나(Fig. 2A) 대조 군의 피부표면은 수많은 각질로 인해 매우 거친 상태였으며 국소적으로 부종이 확인되었다(Fig. 2B). 이러한 대조군에 LES 를 3 회 및 5 회 도포하면 피부 표면의 각질이 없어진 깨끗하고

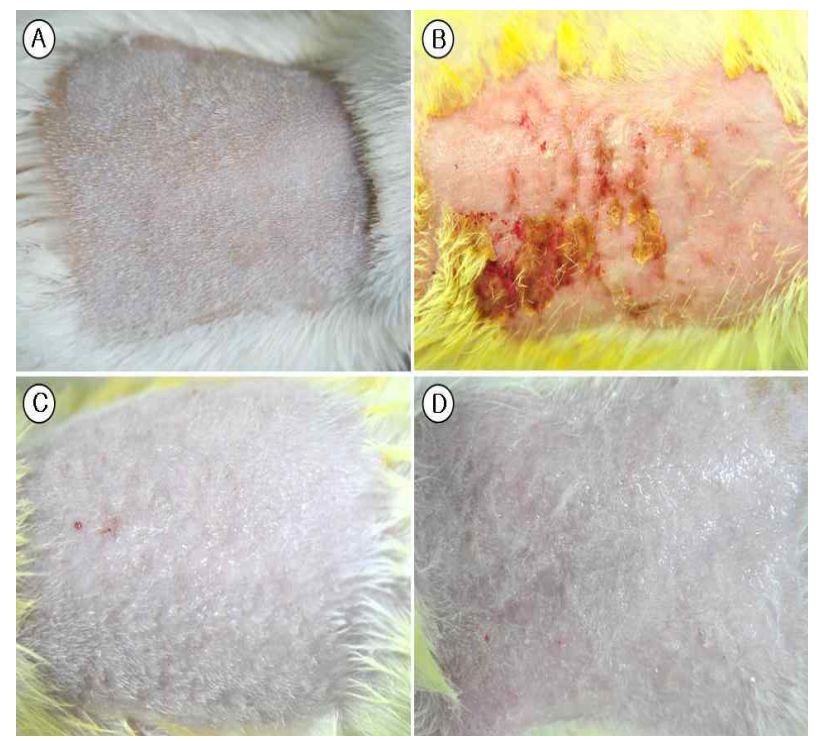

Fig. 1. The effect of LES on DNCB-induced allergic contact dermatitis in Sprague-Dawley rats. (A) untreated groups, (B) groups treated with DNCB alone, (C) groups treated with LES $(17.6 \mathrm{mg} / \mathrm{ml})$ three times after the treatment of DNCB, (D) groups treated with LES $(17.6 \mathrm{mg} / \mathrm{ml})$ five times after the treatment of DNCB.
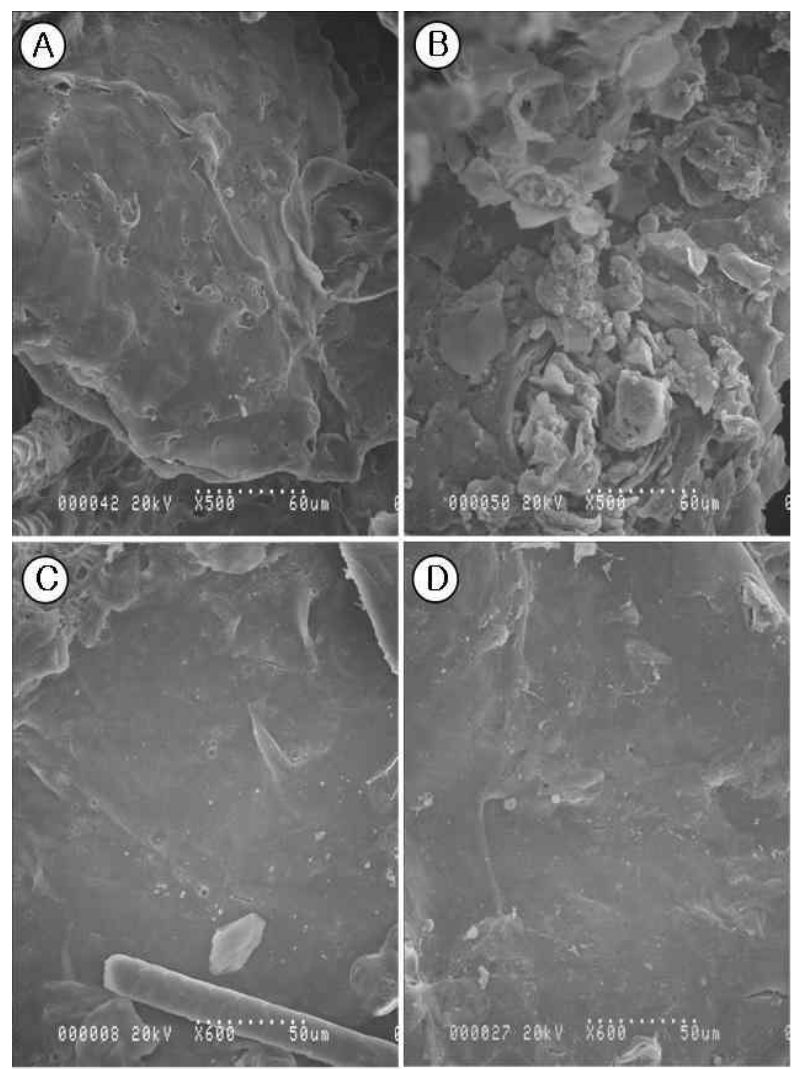

Fig. 2. The effect of LES on DNCB-induced allergic contact dermatitis in Sprague-Dawley rats by scanning electron microscopic comparison (X500). (A) untreated groups, (B) groups treated with DNCB alone, $(C)$ groups treated with LES $(17.6 \mathrm{mg} / \mathrm{ml})$ three times after the treatment of DNCB, (D) groups treated with LES $(17.6 \mathrm{mg} / \mathrm{ml})$ five times after the treatment of DNCB.

매끄러운 상태로 회복되는 것으로 관찰되었다(Fig. 2C, 2D). 또한 조직학적으로 대조군의 피부 조직은 피부표면의 출혈과 표피부의 비대화가 두드러져 정상군의 표피부에 비해 2-3배 이상 두꺼워진 형태로 나타나고 있다. 표피 내에서는 기저층 세포의 소멸이 두드러지게 나타나며, 임파구, 비만세포, 호중 성 백혈구 및 호산성 백혈구와 같은 염증과 관련된 세포들이 표피와 진피층에서 관찰되었다(Fig. $3 \mathrm{~B})$. 그러나 LES를 도포한 실험군에서는 이러한 세포들이 거의 나타나지 않았으며 표피 층의 두께도 점차 정상군과 같은 두께로 회복되고 있는 것으 로 관찰되었다(Fig. 3C, 3D). 알레르기성 접촉피부염의 피부조 직에서는 탈과립화가 일어나는 비만세포와 호산구가 피부조 직에 침윤하며 표피의 과각질화가 일어나게 된다[16,25]. 알레 르기성 접촉피부염이 유발되면 피부표면의 수분 증발이 증가 되어서 항원의 침투가 용이해지므로 피부의 과민반응이 더욱 심화되어 세라마이드에 결합하는 매트릭스 구조단백질에 의 해 형성되는 피부장벽을 약화시키므로 감염과 염증에 대한 감수성이 높아지게 되는 것으로 알려져 있다. 따라서 면역 반 


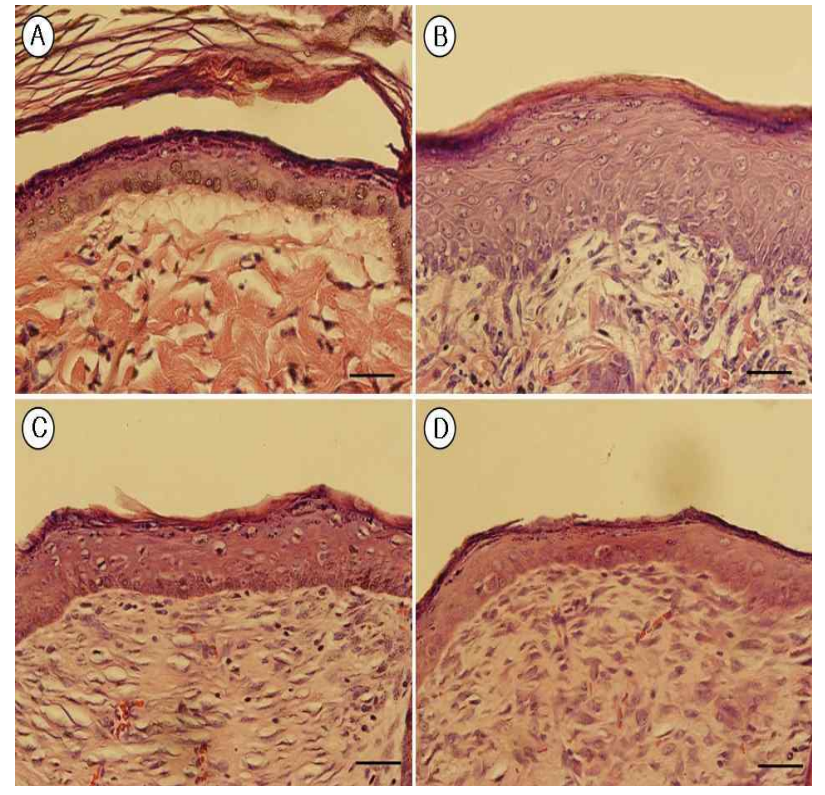

Fig. 3. The effect of LES on DNCB-induced allergic contact dermatitis in Sprague-Dawley rats by microscopic comparison (Scale bar $=50 \mu \mathrm{m})$. (A) untreated groups, (B) groups treated with DNCB alone, $(C)$ groups treated with LES $(17.6 \mathrm{mg} / \mathrm{ml})$ three times after the treatment of DNCB, (D) groups treated with LES $(17.6 \mathrm{mg} / \mathrm{ml})$ five times after the treatment of DNCB.

응에 의한 피부염의 치료를 위해서는 자극을 일으키는 항원을 제거하는 것이 제일 좋은 방법이지만, 특이적 항원을 알 수 없는 경우도 많기 때문에 일반적으로 항생제와 국소적으로 스테로이드 제제를 사용하여 치료하는데 장기간 사용에 대한 안정성에 문제가 많은 것으로 보고되고 있다[22]. 본 연구에서 LES를 알레르기성 접촉피부염이 유발된 피부에 3-5회 도포하 면 매우 효과적인 피부 회복능을 나타내고 있기 때문에 알레 르기성 접촉피부염에 대한 제제로서 가능성을 제시해 주고 있다.

\section{LES가 접촉피부염에 의한 혈장 성분에 미치는 영향}

알레르기성 접촉피부염을 유발했을 때 혈액 성분의 변화를 살펴보면 혈장 내 AST의 수준은 급격히 증가하고 있으나,
$\mathrm{ALT}$ 의 수준은 감소하는 경향을 나타내고 있다(Table 1). 그러 나 LES를 3-5회 처리했을 때 AST의 수치는 감소하고 있으며, $\mathrm{ALT}$ 의 수치는 증가하여 정상군의 수치로 회복되는 경향을 나타내고 있다. 그러나 총 콜레스테롤의 양은 알레르기성 접 촉피부염을 유발하여도 정상군에 비해 거의 차이를 나타내지 않고 있으며, triglyceride의 양은 접촉피부염이 유발되면 급격 히 감소하고 있으나, LES의 처리에 따라 정상군 수준으로 증 가하는 경향을 나타내 주고 있다. Afanasieva와 Lebkova [1]는 랫드에 오가피 제제를 투여하면 지질의 글리코겐으로의 전환 이 증진되고 실험적 심근경색에서 세포의 손상을 감소시키며 triglyceride의 감소가 초래된다고 하였고, Lee 등[15]은 가시 오가피 추출물을 투여한 경우 cholesterol과 triglyceride의 함 량을 억제시킨다고 한 바 있다. Kim과 Park [12]은 DNCB에 의해 유도된 접촉성 피부염 랫드는 지질과산화물이 증가되어 표피의 두께가 증가되고 $\mathrm{SOD}$ 의 활성이 증가된다고 하였다. 이러한 연구 결과로 보아 LES는 알레르기성 접촉피부염이 유 발되어 체내 지질함량이 급격히 증가된 경우 지질함량을 낮춰 정상수준으로 회복시키는 지질함량의 개선에도 관여할 것으 로 생각된다.

LES가 접촉피부염에 의한 혈장 내 $\lg E$ 농도에 미치는 영향

피부 알레르기 반응은 면역글로블린이 항원과 반응하여 방출하는 화학전달물질이나 $\mathrm{T}$ 림프구에 의한 각종 화합물 에 의해 혈관의 확장, 모세혈관의 투과성 항진, 점액의 증가 및 점막의 부종과 염증들을 유발시킨다. 특히 접촉피부염은 $\mathrm{TH} 2$ 세포가 관련되어 있으며 $\mathrm{IgE}$ 의 증가와 연관되어 있다 [8]. 본 연구에서 혈장 내 $\mathrm{IgE}$ 의 수준을 측정해 보면 알레르 기성 접촉피부염을 유발했을 때 정상군에 비해 $\mathrm{IgE}$ 의 수준 이 증가하였으나 LES를 처리하였을 때 점차 감소하여 정상 군과 유사한 수준으로 감소되고 있다(Fig. 4). 최근 0-25\% trimellitic anhydride (TMA)와 0-3\% DNCB로 접촉피부염을 유도한 마우스의 $\mathrm{IgE}$ 수준은 최대 4-5배 증가한다고 연구 보고된 바 있는데[2], 본 연구에서도 LES를 도포하면 혈장 내 $\operatorname{IgE}$ 수준이 대조군에 비해 정상군 수준으로 감소하고 있 기 때문에 면역 염증반응을 감소시켜 피부의 과민반응 해소 에 관여할 것으로 생각된다.

Table 1. The effect of LES on the plasma level of AST, ALT, total cholesterol and triglyceride in DNCB-treated Sprague-Dawley rats

\begin{tabular}{lcccc}
\hline Item group & Normal & Control & LES-3 & LES-5 \\
\hline AST (IU/l) & $215 \pm 2.68$ & $343 \pm 4.81$ & $294 \pm 3.47$ & $228 \pm 3.11$ \\
ALT (IU/l) & $80 \pm 1.44$ & $63 \pm 1.86^{*}$ & $68 \pm 2.45$ & $77 \pm 2.32$ \\
Total cholesterol $(\mathrm{mg} / \mathrm{dl})$ & $78 \pm 2.46$ & $80 \pm 4.54$ & $86 \pm 2.56$ & $82 \pm 1.89^{*}$ \\
Triglyceride $(\mathrm{mg} / \mathrm{dl})$ & $81 \pm 4.6$ & $51 \pm 1.46$ & $67 \pm 1.22^{*}$ & $56 \pm 1.43$ \\
\hline
\end{tabular}

${ }^{*} p<0.05$ indicates a significant difference between the normal group and control group or between the control group and LES-treated group.

*LES-3 and LES-5 mean the treatment of LES $(17.6 \mathrm{mg} / \mathrm{ml})$ three times and five times, respectively. 


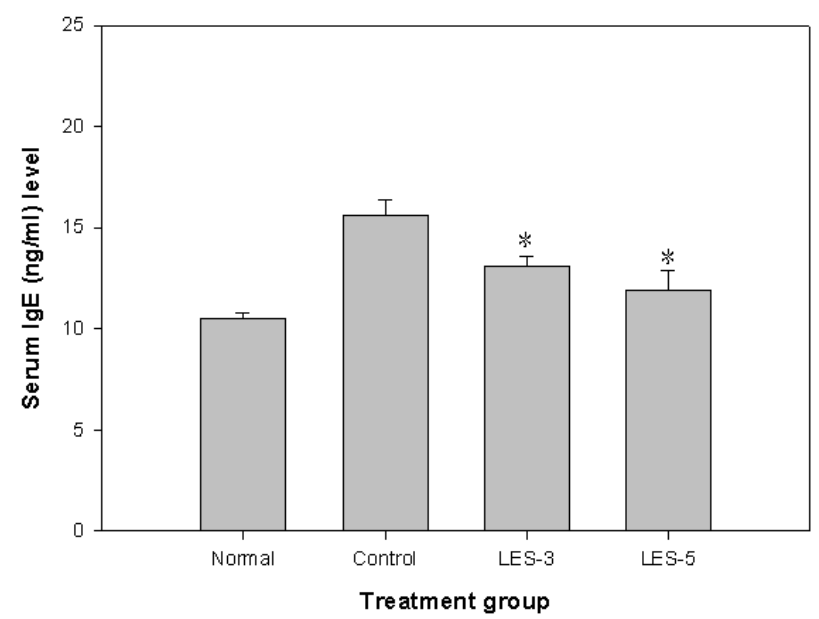

Fig. 4. The effect of LES on serum IgE level of DNCB-treated Sprague-Dawley rat. LES-3 and LES-5 mean the treatment of LES $(17.6 \mathrm{mg} / \mathrm{ml})$ three times and five times, respectively. " $p<0.05$ indicates a significant difference between the normal group and control group or between the control group and LES-treated group.

LES가 접촉피부염에 의한 iNOS와 COX-2 발현에 미치 는 영향

Nitric oxide $(\mathrm{NO})$ 는 높은 반응성을 가진 생체 생성 분자로써 신경전달, 혈관의 이완 및 세포 매개성 면역 반응에 관여하며, 특히 대식세포가 interferon- $\gamma$ (IFN- $\gamma$ ) 또는 lipopolysacchride (LPS)가 자극될 때 inducible NOS (iNOS)가 발현되어 많은 양의 $\mathrm{NO}$ 을 생성하게 되며 염증반응 매개물질의 역할을 하게 된다[18]. 일반적으로 $\mathrm{NO}$ 는 박테리아를 죽이거나 종양을 제 거 시키는 중요한 역할을 하지만, 병리적인 원인에 의한 과도 하게 생성된 $\mathrm{NO}$ 는 염증을 유발시키게 되며 조직의 손상, 유전

A
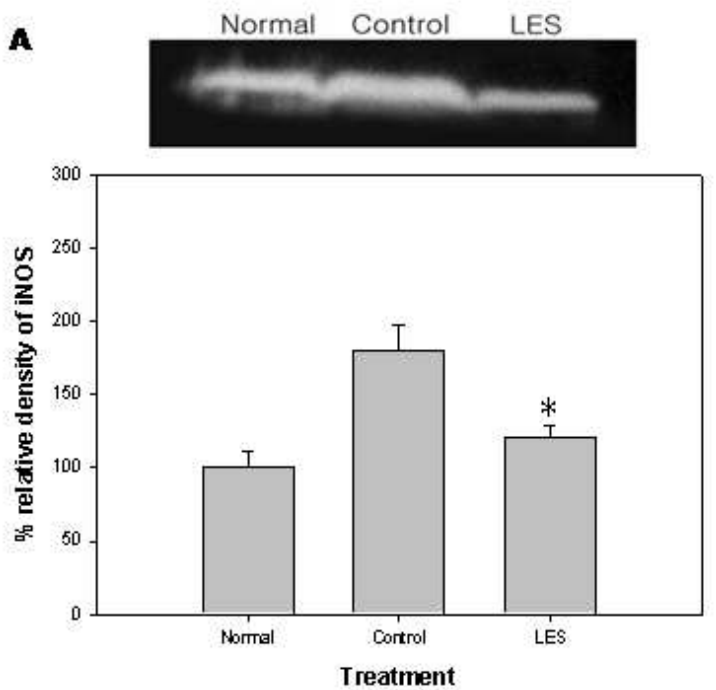

자 변이 및 신경 손상 등을 유발하기도 한다 $[17,23,26]$. 이와 더불어 염증반응에 의해 활성화된 대식세포는 TNF- $a$ 와 같은 pro-inflammatory cytokine과 cyclooxygenase-2 (COX-2)와 같은 염증 매개물질을 과량 생산하게 된다. 염증 매개물질이 과량 생산되면 과도한 면역 반응을 야기하게 되고 이로 인해 각종 인체 질환을 악화시키는 원인이 되기도 한다[19]. 본 연구 에서도 염증 반응과 관련된 유전자의 반응을 살펴보기 위하여 $\mathrm{iNOS}$ 와 COX-2의 활성을 살펴보았다. iNOS와 COX-2의 활성 은 인위적으로 유발된 알레르기 접촉피부염 상태에서는 이의 활성이 매우 증가되고 있으나, $\mathrm{LES}$ 를 접촉피부염 부위에 도포 하게 되면 $\mathrm{iNOS}$ 와 COX-2의 활성은 정상군과 유사한 수준으 로 염증 활성이 감소되는 것으로 나타났다(Fig. 5A, 5B). Kim 등[11]은 오동나무(Paulownia coreana) 잎 추출물이 $\mathrm{NO}$ 와 $\mathrm{PGE}_{2}$ 를 생성하는 $\mathrm{iNOS}$ 와 COX-2의 발현양을 효과적으로 억 제하여 항암효과가 있다고 보고한 바 있고, Cichoki 등[4]에 의하면 마우스의 피부발암에 있어서 가장 강력한 프로모터로 알려진 12-O-tetradecanoylphorbol-13-acetate (TPA)와 protocatechuic acid (PCA), tannic acid (TA) 및 chlorogenic acid $(\mathrm{CHA})$ 를 각각 마우스의 표피에 처리한 결과 $\mathrm{iNOS}$ 의 발현 억 제효과는 PCA가 가장 높았으며 COX-2의 발현 억제에 있어서 는 TA가 가장 높은 활성을 보인다고 하였다. 본 연구에서도 LES는 알레르기 접촉피부염에 의한 iNOS와 COX-2의 발현을 감소시켜 과도한 염증 반응을 억제하는 데 효과적일 것으로 생각된다.

LES 내 lunasin의 세포 내 전달 기작

LES의 전달 경로를 살펴보기 위하여 피부 조직절편에 DAPI와 lunasin 항체를 처리하였다. 정상군, 대조군 및 실험 군에서 DAPI 처리 시 표피세포의 핵에 염색이 되고 있으나

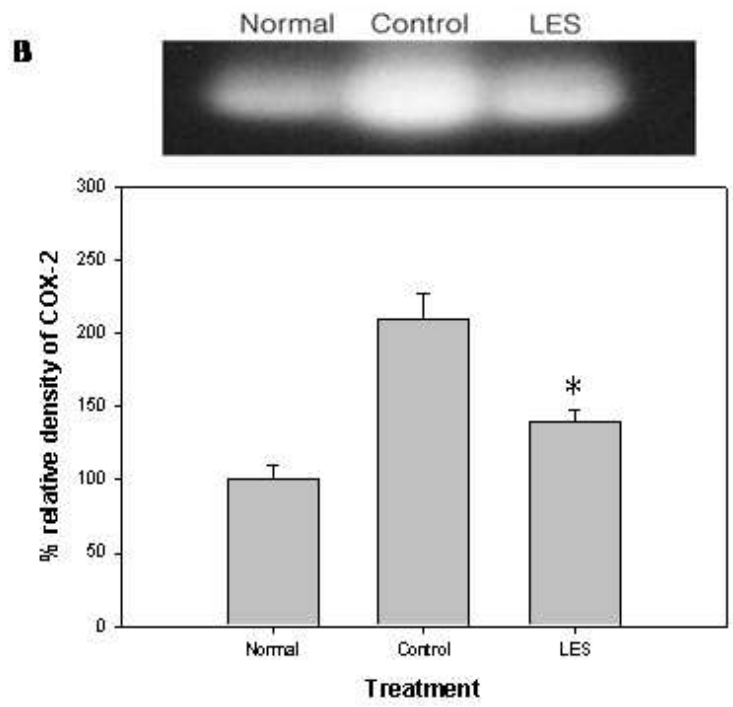

Fig. 5. The effect of LES on the expressions of iNOS (A) and COX-2 (B) on DNCB-treated Sprague-Dawley rat. " $p<0.05$ indicates a significant difference between the normal group and control group or between the control group and LES-treated group. 
(Fig. 6A, 6C, 6E-blue-DAPI stain) LES를 처리하지 않은 정상 군과 대조군에서는 lunasin에 대한 반응이 나타나지 않았으며 (Fig. 6B, 6D-green fluorescent stain), 단지 LES가 도포된 피부 세포의 경우 LES에 포함된 주성분 중 하나인 lunasin이 세포 침투와 함께 핵 내로 이동하는 것으로 확인되었다(Fig. $6 \mathrm{~F})$. Lunasin의 고유한 특징 중 하나는 외부에서 세포에 처리하는 경우 대부분 핵 내로 이동하며, 핵 내에서 탈아세틸화된 히스 톤과 작용하여 항암 활성을 나타내는 것으로 보고되고 있다 $[5,14]$. 또한 Galvez 등[7]은 lunasin은 정상적인 세포에는 영향 을 미치지 않지만 변형된 암세포에는 apoptosis를 유발하여 암세포를 상당히 감소시키는 것으로 보고하여 lunasin을 새로 운 chemopreventive agent로 제시한 바 있다. 본 연구에서도 알레르기성 접촉피부염에 LES를 처리하면 LES에 포함된 lunasin은 세포표면에 뿐만 아니라 세포 내 핵 속으로 이동하는 것으로 확인되어 이는 전체 유전자 또는 일부 유전자의 발현 에 영향을 미쳐 알레르기성 접촉피부염의 완화에 기여할 것으 로 추측된다. 그러나 LES의 작용 기작에 대해서는 향후 LES와 관련된 유전자의 동정과 조절메커니즘 입증에 대한 추후 연구 가 필요할 것으로 사료된다.

DAPI
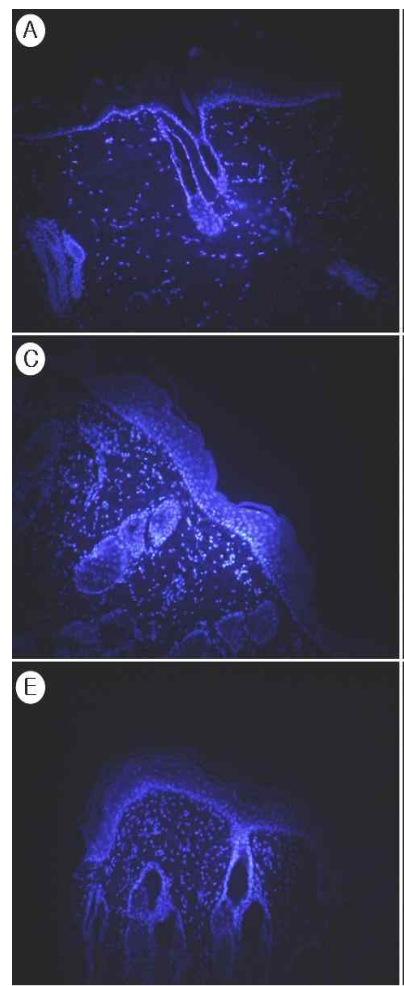

Fig. 6. Internalization of the lunasin from LES into the nucleus of rat epidermal cells. A, B: DAPI (blue) and lunasin (green) of untreated groups, C, D: DAPI (blue) and lunasin (green) of groups treated with DNCB alone, E, F: DAPI (blue) and lunasin (green) of groups treated with LES after the treatment of DNCB.

\section{감사의 글}

이 논문은 농림기술개발센터(ARPC)의 농림기술개발과제 (No. 307003)에 의해 수행되었기에 이에 감사드립니다.

\section{References}

1. Afanasieva, T. N. and N. P. Lebkova. 1987. Effect of Eleutherococcus on the subcellular structures of the heart in experimental myocardial infarct. Biull. Eksp. Biol. Med 103, 212-215.

2. Ban, M. and D. Hettich. 2001. Relationship between IgE positive cell numbers and serum total IgE levels in mice treated with trimellitic anhydride and dinitrochlorobenzene. Toxicol. Lett. 118, 129-137.

3. Choi, K. U. and D. M. Paek. 1995. Asthma and air pollution in korea. Korean J. Epidemiol. 17, 64-75.

4. Cichocki, M., J. Blumczynska, and W. Baer-Dubowska. 2010. Naturally occurring phenolic acids inhibit 12-O-tetradecanoylphorbol-13-acetate induced NF- $\mathrm{B}$, iNOS and COX-2 activation in mouse epidermis. Toxicology 268, 118-124.

5. De Lumen, B. O. 2005. Lunasin: a cancer-preventive soy peptide. Nutr. Rev. 63, 16-21.

6. Galvez, A. F. and B. O. de Lumen. 1999. A soybean cDNA encoding a chromatin-binding peptide inhibits mitosis of mammalian cells. Nat. Biotechnol. 17, 495-500.

7. Galvez, A. F., N. Chen, J. Macasieb, and B. O. de Lumen. 2001. Chemopreventive property of a soybean peptide (lunasin) that binds to deacetylated histones and inhibits acetylation. Cancer Res. 61, 7473-7478.

8. Ishizaka, K. 1984. Regulation of IgE synthesis. Ann. Rev. Immunol. 2, 159-182.

9. Kim, H. H. and D. H. Kim. 2001. The effect of yunkyopaedosangamibang on allergic contact dermatitis. J. Institute Oriental Medicine of Semyung University 3, 67-80.

10. Kim, M. H., M. C. Kim, J. S. Park, J. W. Kim, and J. O. Lee. 2001. The antioxidative effects of the water-soluble extracts of plants used as tea materials. Korean J. Food Sci. Technol. 33, 12-18.

11. Kim, N. K., M. H. Kim, C. S. Yoon, and S. W. Choi. 2006. Studies on the anti-inflammatory activity of Paulownia coreana uyeki leaf extract. J. Soc. Cosmet. Scientists Korea 32, 241-247.

12. Kim, Y. H. and Y. S. Park. 2006. Effect of Acanthopanacis cortex water extract on antioxidative activity, lipid profile and epidermal thickness in DNCB-induced allergic contact dermatitis animal model. Korean J. Food Sci. Technol. 38, 668-673.

13. Kwon, O. S., J. T. Kim, I. S. Park, S. H. Ahn, H. P. Lee, H. H. Kim, and Y. H. Gang. 1999. The effect of yunkyopaedosangamibang on allergic contact dermatitis. J. Institute Oriental Medicine of Semyung University 8, 77-91.

14. Lam, Y., A. F. Galvez, and B. O. de Lumen. 2003. Lunasin suppresses E1A-mediated transformation of mammalian cells but does not inhibit growth of immortalized and estab- 
lished cancer cell lines. Nutr. Cancer 47, 88-94.

15. Lee, Y. S., S. H. Jung, S. S. Lim, J. Ji, S. H. Lee, and K. H. Shin. 2001. Effect of the water extract from the stem bark of Acanthopanax senticosus on hyperlipidemia in rats. Korean J. Pharmacogn. 32, 103-107.

16. Matsuda, H., N. Watanabe, G. P. Geba, J. Sperl, M. Tsudzuki, J. Hiroi, M. Matsumoto, H. Ushio, S. Saito, P. W. Askenase, and C. Ra. 1997. Development of atopic dermatitis-like skin lesion with $\mathrm{IgE}$ hyperproduction in $\mathrm{NC} / \mathrm{Nga}$ mice. Int. Immunol. 9, 461-466.

17. McCartney-Francis, N., J. B. Allen, D. E. Mizel, J. E. Albina, Q. W. Xie, C. F. Nathan, and S. M. Wahl. 1993. Suppression of arthritis by an inhibitor of nitric oxide synthase. J. Exp. Med 178, 749-754.

18. Miyasaka, N. and Y. Hirata. 1997. Nitric oxide and inflammatory arthritides. Life Sci. 61, 2073-2081.

19. Needleman, P. and P. C. Isakson. 1997. The discovery and function of COX-2. J. Rheumatol. Suppl. 49, 6-8.

20. Park, I. Y., T. S. Park, S. W. Oh, J. H. Woo, H. E. Jin, and H. R. Park. 2002. The effect of Eleutherococcus senticosus on human fatigue factors and oxidant-antioxidant system during maximal and submaximal exercise. Korean J. Physic. Edu. 41, 305-315.
21. Park, J. H., S. Y. Kim, B. O. de Lumen, K. J. Lee, and H. J. Jeong. 2002. Identification and bioavailability of a chromatin-binding peptide (lunasin) from korean soybean. J. Plant Biol. 45, 96-101.

22. Sator, P. G., J. B. Schmidt, and H. Honigsmann. 2003. Comparison of epidermal hydration and skin surface lipids in healthy individuals and in patients with atopic dermatitis. J. Am Acad Dermatol. 48, 352-358.

23. Stuehr, D. J. and M. A. Marletta. 1985. Mammalian nitrate biosynthesis: mouse macrophages produce nitrite and nitrate in response to Escherichia coli lipopolysaccharide. Proc. Natl. Acad Sci. USA 82, 7738-7742.

24. Tasaka, K. 1986. Anti-allergic drugs. Drug of Today 22, 101-133.

25. Vestergaard, C., H. Yoneyama, M. Murai, K. Nakamura, K. Tamaki, Y. Terashima, T. Imai, O. Yoshie, T. Irimura, H. Mizutani, and K. Matsushima. 1999. Overproduction of Th2-specific chemokines in NC/Nga mice exhibiting atopic dermatitis like lesions. J. Clin. Invest. 104, 1097-1105.

26. Weisz, A., L. Cicatiello, and H. Esumi. 1996. Regulation of the mouse inducible-type nitric oxide synthase gene promoter by interferon-gamma, bacterical lipopolysaccharide and NG-monomethyl-L-arginine. Biochem J. 316, 209-215.

\section{초록 : 대두 추출물 LES가 DNCB로 유도된 랫드의 알레르기성 접촉피부염에 미치는 영향 \\ 김정숙 ${ }^{1} \cdot$ 박영미 $^{1} \cdot$ 정진부 ${ }^{2} \cdot$ 임재환 $^{1} \cdot$ 정형진 $^{2} \cdot$ 서을원 $^{1} \star$ \\ ('안동대학교 자연과학대학 생명과학과, ${ }^{2}$ 안동대학교 자연과학대학 생약자원학과)}

본 연구에서는 대두 추출물인 LES가 DNCB에 의해 인위적으로 접촉피부염을 유발시킨 랫드의 피부 회복능에 미치는 효과를 조사하였다. 알레르기 접촉피부염이 유발된 피부에 LES $17.6 \mathrm{mg} / \mathrm{ml}$ 를 3-5회 도포하여 피부 표면 을 조직학적 분석하여 본 결과 각질이 제거된 깨끗하고 매끄러운 상태로 되었으며, 비후화된 표피층의 두께도 점차 정상군과 같은 두께로 회복시키는 효과를 나타냈다. 또한 LES는 체내 지질함량을 낮춰 정상수준으로 회복 시키는 지질함량의 개선에 효과적으로 작용하고 있으며, 혈장 내 $\mathrm{IgE}$ 의 수준도 정상군 수준으로 감소시키고 있으 며, LES에 의해 염증 반응과 관련된 $\mathrm{NOS}$ 와 COX-2의 활성도 감소되어 피부의 과민반응 해소에 관여하는 것으로 생각된다. LES에 포함된 주 성분 중 하나인 lunasin은 세포 침투와 함께 핵 내로 이동하는 것으로 확인되어 전체 유전자 또는 일부 유전자의 발현을 조절하는 데 관여할 것으로 추측된다. 이러한 결과로 보아 LES는 알레르기성 접촉피부염에 매우 효과적인 치료 효과를 나타내고 있기 때문에 기존의 알레르기성 접촉피부염 치료제를 대체할 수 있는 제제로서 응용이 기대된다. 